\title{
PERAN KELOMPOK TANI DALAM PENGEMBANGAN USAHA KOPI DI DESA SETILING KECAMATAN BATUKLIANG UTARA KABUPATEN LOMBOK TENGAH
}

\section{THE ROLE OF FARMER GROUPS IN DEVELOPMENT OF THE COFFE BUSINESS IN SETILING VILLAGE NORTH BATUKLIANG SUB-DISTRICT OF CENTRAL LOMBOK REGENCY}

\author{
Baiq Ririen Eka Mahendrayanti, Siti Nurjannah, Nuning Juniarsih \\ Program Studi Agribisnis Fakultas Pertanian Universitas Mataram \\ E-mail:
}

\begin{abstract}
ABSTRAK
Penelitian ini bertujuan untuk: (1) Mengetahui peran kelompok tani dalam pengembangan usaha kopi di Desa Setiling Kecamatan Batukliang Utara Kabupaten Lombok Tengah(2) Mengetahui kendala-kendala dalam pengembangan kelompok tani kopi. Hasil penelitian menunjukkan bahwa (1) Peran kelompok tani di Desa Setiling termasuk kedalam kategori "Berperan". Adapun peran kelompok tani dapat dibedakan menjadi beberapa variabel yaitu wadah belajar, wadah kerjasama dan unit produksi. Dari penelitian yang sudah dijalankan didapatkan hasil peran kelompok tani sebagai wadah belajar sebesar 56,7\%, wadah kerjasama 26,7\% dan unit produksi sebesar 50\%. Dapat dilihat bahwa peran kelompok tani dalam pengembangan usaha kopi yang berjalan optimal adalah wadah belajar dan unit produksi.
\end{abstract}

Kata kunci: Kelompok Tani, Peran, Wadah Belajar, Wadah Kerjasama, Unit Produksi.

\section{ABSTRACK}

This study aims to: 1) Determine the role of groups in the development of farmer groups in Setiling Village, North Batukliang District, Central Lombok Regency. 2) Knowing the constrainta in developiing coffe farmer groups. The results showed that 1) The role of the farmer groups in Setiling Village included in the "Role" category. The role of farmer groups can be divided into several variables, namely learning container, cooperation forum and production unit. Forum the research that has been carried out, the results of the role of farmer groups as a learning container are 56,7\%, cooperation institutions are 26,7\% and the production unit is $50 \%$. It can be seen that the role of groups is a learning container and production unit.

Keywords: Farmers Group, Role,Learning Container, Container of Cooperation, Production Unit. 


\section{PENDAHULUAN}

\section{Latar Belakang}

Pertanian di Indonesia dapat di katakan sebagai roda penggerak perekonomian nasional. Selain menghasilkan bahan pangan untuk memenuhi kebutuhan masyarakat, pertanian juga sedang menjadi prioritas untuk ditingkatkan produktivitasnya. Pada tahun 2017 produksi padi nasional mengalami pertumbuhan 2,56\% dibanding tahun sebelumnya. Produksi jagung juga meningkat 18,55\%. Peningkatan ini bisa terjadi karena terus berkembangnya sistem irigasi untuk sawah-sawah yang ada sehingga tidak lagi menjadi sawah tadah hujan. Dari data terakhir persentase luas lahan sawah irigasi sudah mencapai 58,41\% atau sekitar 4,78 juta hektar dan sisanya masih berupa sawah non irigasi. Salah satu syarat pelancar pembangunan pertanian adalah adanya kegiatan petani yang tergabung dalam kelompok tani. Mengembangkan kelompok tani berarti membangun kemauan, dan kepercayaan pada diri sendiri agar terlibat secara aktif dalam pembangunan (Dinas Pertanian Provinsi,2017).

Komoditi unggulan kabupaten Lombok Tengah adalah komoditi dari sektor pertanian dan jasa. Komoditi unggulan pada sektor pertanian adalah sub sektor tanaman perkebunan dengan komoditi kakao, kopi, kelapa,tembakau dan jambu mete. Ketersediaan lahan perkebunan di kabupaten Lombok Tengah seluas 118.992 ha. Sementara pemanfaatan potensi perkebunan baru mencapai 36.998,07 ha atau 31,09\% (Dinas Pertanian Lombok Tengah,2017)

Wilayah Kecamatan Batukliang Utara merupakan wilayah pengembangan komoditas perkebunan yang meliputi komoditas unggulan seperti tembakau virgina, jambu mete dan kopi. Dilihat dari data Dinas Pertanian Kabupaten Lombok Tengah, kopi menjadi komoditas yang paling banyak dikembangkan di kecamatan Batukliang Utara, yang dibuktikan dari besarnya luas areal tanam dan produksi yang dihasilkan. Total areal seluas 804,50 Ha dengan jumlah produktivitas sebesar $580 \mathrm{~kg} / \mathrm{Ha}$. Salah datu Desa penghasil kopi di kecamatan Batukliang Utara adalah di Desa Setiling dengan areal perkebunan seluas 700 ha, yang dikelola secara sederhana dan tradisional. Di desa ini terdapat 3 kelompok tani kopi yaitu kelompok tani "Beriuk Demen", "Suka Maju", dan "Mekar Baru".

Berdasarkan pengamatan peneliti di lapangan, kelompok tani di desa Setiling tersebut keaktifannya beragam, yaitu ada kelompok tani yang mampu berperan aktif sesuai dengan fungsi kelompok tani, dan ada yang kurang aktif. Masalah lain yang ditemukan pada kelompok tani ini adalah sebagian dari anggota kelompok tani kopi tersebut melakukan diversifikasi lahan dengan alasan untuk mencukupi kebutuhan, sehingga ini menyebabkan para petani tersebut tidak hanya terfokus pada tanaman kopi saja. Program diversifikasi yang merupakan usaha campur tangan manusia antara tanaman yang lain seperti tumpang sari, tumpang gilir dan lain sebagainya.

Kondisi tersebut kemudian memunculkan pertanyaan bagaimana peran kelompok tani yang ada di Desa Setiling? Oleh sebab itu maka perlu dilakukan penelitian yang berjudul "Peran Kelompok tani dalam Pengembangan Usaha Kopi di Desa Setiling Kecamatan Batukliang Utara Kabupaten Lombok Tengah”.

Rumusan Masalah

Berdasarkan uraian diatas, maka dapat dirumuskan permasalahan sebagai berikut:

1. Bagaimana peran kelompok tani dalam pengembangan usaha kopi di Desa Setiling Kecamatan Batukliang Utara Kabupaten Lombok Tengah?

2. Apa saja kendala-kendala petani dalam pengembangan usaha kopi di Desa Setiling Kecamatan Batukliang Utara Kabupaten Lombok Tengah?

\section{Tujuan Penelitian}

Penelitian ini bertujuan untuk:

1. Untuk mengetahui peran kelompok tani dalam pengembangan usaha kopi di Desa Setiling Kecamatan Batukliang Utara Kabuoaten Lombok Tengah.

2. Untuk mengetahui kendala-kendala yang dihadapi petani dalam pengembangan usaha kopi di Desa Setiling Kecamatan Batukliang Utara Kabupaten Lombok Tengah.

\section{Kegunaan Penelitian}

Penelitian ini diharapkan berguna bagi:

1. Peneliti, untuk menambah wawasan dan pengetahuan yang lebih luas mengenai peran kelompok dalam pengembangan kelompok tani.

2. Petani, Sebagai bahan informasi untuk kelompok tani dalam pengembangan kelompok tani kopi di Desa Setiling.

3. Pembaca, diharapkan dapat memberikan pengetahuan dan tambahan referensi terutama untuk peneliti selanjutnya yang akan menyusun penelitian selanjutnya. 


\section{METODE PENELITIAN}

Data primer dalam penelitian ini diperoleh melalui wawancara terstruktur yang menggunakan instrumen kuisioner yang ditujukan kepada responden dengan cara memberikan pertanyaan langsung kepada responden. Sedangkan pengumpulan data sekunder dilakukan dengan cara mengumpulkan data ataupun informasi dari instansi-intansi terkait yaitu BPS, Dinas Petanian Kabupaten Lombok Tengah dan UPT-HPT kecamatan Batukliang Utara. Teknik pengambilan sampel yang digunakan adalah purposive sampling, quota samping, dan proportional random sampling. Data yang diperoleh dianalisis menggunakan variabel dan pengukuran dengan menggambarkan peran kelompok sebagai wadah belajar wadah kerjasama dan unit produksi yang merupakan indikator dari peran kelompok dan kendala-kendala yang di hadapi anggota kelompok dalam melaksanakan kegiatan kelompok dalam rangka perwujudan peran kelompok.

Responden petani kopi ditetapkan secara quota sampling sebanyak 30 orang dari 3 kelompok tani. Dalam hal ini diambil 2 (dua) orang yang dijadikan responden yaitu pengurus ( ketua dan sekretaris) yang ditentukan dengan cara purposive sampling, dan anggota kelompok tani ditentukan dengan menggunakan teknik proporsional random sampling yaitu jumlah responden yang diambil sesuai dengan proporsi anggota yang ada dalam kelompok

\section{Analisis Data}

Untuk mengetahui peran kelompok dinilai berdasarkan skor yang diperoleh dengan kriteria yang telah ditetapkan.

- Skor maksimum $=\sum$ item $x \sum$ skor tertinggi

- Skor minimum $=\sum$ item $\times \sum$ skor terendah

- Interval skor $\quad=$ jumlah skor maks - jumlah skor min Jumlah kategori

\section{HASIL DAN PEMBAHASAN}

Peran Kelompok dalam Pengembangan Kelompok Tani

Pengembangan kelompok tani adalah serangkaian proses kegiatan memampukan dan memberdayakan kumpulan anggota kelompok yang mempunyai tujuan bersama. Upaya pengembangan kelompok tani juga memerlukan pemahaman dan keterampilan manajerial, karena kelompok tani diharapkan maju dan berkembang memiliki unit-unit usaha jasa saprotan, pengolahan, dan permodalan (Badan Penyuluhan dan Pengembangan SDM Pertanian, 2013).

Oleh karena itu kelompok tani mempunyai fungsi atau peranan dalam pengembangan kelompok tani yaitu (1). Sebagai wadah belajar, (2). Sebagai wadah kerjasama, (3). Sebagai unit produksi.

Hasil penelitian menunjukkan bahwa peran kelompok tani di Desa Setiling sebagai wadah belajar, wadah kerjasama dan unit produksi termasuk kedalam kategori "Berperan" dimana skor yang didapatkan sebanyak 52 melalui kriteria peran kelompok. Hasil tersebut dapat dilihat pada Tabel 1 dibawah.

Tabel 1. Tingkat Peran Kelompok Tani Sebagai Wadah Belajar Wadah Kerjasama, dan Unit Produksi Tahun 2019

\begin{tabular}{llll}
\hline No & Peran Kelompok & Total Skor & Kategori \\
\hline 1 & Wadah Belajar & 30 & Berperan \\
2 & Wadah Kerjasama & 12 & Kurang Berperan \\
1 & Unit Produksi & 10 & Berperan \\
\hline Jumlah Tingkat Peran Kelompok & 52 & Berperan \\
\hline
\end{tabular}

Sumber : Data primer diolah Tahun 2019

\section{Peran Kelompok Tani Sebagai Wadah Belajar}

Wadah belajar merupakan wadah bersama bagi anggota kelompok tani yang bertujuan untuk meningkatkan pengetahuan, sikap dan keterampilan. Berdasarkan hasil penelitian peran kelompok tani sebagai wadah belajar di Desa Setiling termasuk dalam kategori "Berperan", Berikut hasil pengukuran seberapa banyak anggota kelompok yang ikut berperan dalam peran kelompok sebagai wadah belajar dapat dilihat pada tabel 2 dibawah ini. 
Tabel 2. Jumlah Responden yang Berperan dalam Wadah Belajar di Desa Setiling Tahun 2019

\begin{tabular}{lcrr}
\hline \multirow{2}{*}{ Wadah Belajar } & \multirow{2}{*}{ Interval } & Jumlah Responden \\
\cline { 3 - 4 } & & Orang & $\%$ \\
\hline Berperan & $29-36$ & 17 & 56,7 \\
Kurang Berperan & $21-28$ & 13 & 43,3 \\
Tidak Berperan & $12-20$ & 0 & 0 \\
\hline Jumlah & & 30 & 100,0 \\
\hline
\end{tabular}

Sumber: Data primer diolah Tahun 2019

Berdasarkan hasil penelitian didapatkan jumlah responden yang berpartisipasi dalam kegiatan ini lebih banyak, jumlah reponden tersebut sebanyak 17 orang $(56,7 \%)$ dari 30 responden yang ada. Hal ini menggambarkan bahwa peran kelompok tani sebagai wadah belajar di Desa Setiling berjalan dengan sangat baik, peran kelompok tani dapat dilihat dari 4 indikator yang digunakan dalam penelitian untuk mengukur seberapa besar peran kelompok tani sebagai wadah belajar. Indikator yang dimaksud antara lain sebagai berikut:

\section{Pertemuan rutin}

Pertemuan rutin yang artinya pertemuan antar kelompok dengan semua anggota kelompok dalam waktu tertentu, pertemuan rutin kelompok dilaksanakan dalam 1 bulan sekali yang nantinya akan diisi dengan kegiatan atau aktivitas kelompok yang bertempatkan disebuah ruangan yang telah disiapkan oleh kelompok seperti sekretariat kelompok atau rumah anggota kelompok sesuai dengan kesepakatan anggota.

\section{Diskusi kelompok}

Diskusi Kelompok yang dimaksud yaitu pertemuan antar beberapa anggota kelompok diluar pertemuan rutin, diskusi kelompok dapat meningkatkan pengetahuan anggota kelompok dari bahan atau tema yang didiskusikan. Topik yang dibahas dalam diskusi kelompok juga seputar usahatani masalah hama atau penyakit, dari diskusi tersebut petani saling berbagi pengalaman yang mereka ketahui dalam menangani masalah-masalah tersebut dan petani yang berdiskusi dari semulanya tidak tahu menjadi tahu. Hal tersebut sudah sejalan dengan Fitriansyah (2011) dalam Mailina (2018) yaitu: mengemukakan dan memahami keinginan, pendapat maupun masalah yang dihadapi anggota kelompok dan merumuskan kesepakatan bersama, baik dalam memecahkan masalah maupu untuk melakukan berbagai kegiatan kelompok tani.

\section{kegiatan pelatihan}

Kegiatan pelatihan yaitu kegiatan belajar yang dilakukan oleh anggota kelompok dalam meningkatkan pengetahuan. Pelatihan yang pernah diikuti anggota kelompok yang diundang oleh pihak dinas yaitu UPH (Unit Pengolahan Hasil) agroindustri kopi bubuk pada tahun 2015. Kegiatan ini membahas tentang bagaimana pengolahan kopi bubuk yang dihasilkan menjadi suatu kopi yang terkenal dan laris dipasaran dengan menggunakan sarana dan prasarana pengolahan kopi yang dimiliki oleh kelompok yang semuanya merupakan bantuan dari Pemerintah Pusat. Ditinjau dari inisiatif kelompok, pada tahun 2017 kelompok pernah menyelenggarakan pelatihan untuk kebutuhan anggota-anggota dalam kelompok. Kegiatan bermula dari inisiatif ketua kelompok yang kemudian didukung oleh anggota, selanjutnya ketua kelompok berdiskusi dengan PPL dan mendatangkan tutor dari Dinas Pertanian Kabupaten.

\section{Studi Banding}

Studi banding adalah kegiatan belajar dalam rangka mengunjungi pihak luar lingkungan kelompok. Studi banding yang diikuti mengenai tanaman hortikultura, kegiatan studi banding ini diselenggarakan oleh salah satu perusahaan di Bogor pada tahun 2015. Studi banding ini bertujuan untuk mengenalkan cara modern melakukan budidaya tanaman hortikultura seperti cara budidaya tomat, kentang dan kubis. Studi banding atas inisiatif kelompok tani juga hanya pernah diadakan 2 kali saja. Studi banding dalam rangka yang dikunjungi oleh kelompok lain pada tahun 2018 yang bertujuan untuk melihat keberhasilan cara mengolah kopi. Dari kegiatan studi banding yang dilaksanakan di dalamnya terdapat kegiatan seperti pameran, pada tahun 2015 kelompok tani mengikuti pameran di TMII yang diikuti oleh sebagian anggota.

\section{Peran Kelompok Sebagai Wadah Kerjasama}

Kelompok tani sebagai wadah kerjasama merupakan wadah sarana dalam membangun relasi untuk memenuhi kebutuhan dalam kegiatan usahatani yang dijalankan anggotanya. Peran kelompok tani sebagai wadah kerjasama dapat diukur dengan beberapa indikator seperti kerjasama antar anggota kelompok dan kelompok lain dan bermitra dengan pihak luar.

Hasil tersebut dapat dilihat dalam Tabel 3 di bawah, dimana semua indikator peran kelompok tani sebagai wadah kerjasama telah digunakan untuk mengukur seberapa banyak anggota kelompok yang ikut berperan dalam peran kelompok sebagai wadah kerjasama. 
Tabel 3. Jumlah Responden yang Berperan dalam Wadah Kerjasama di Desa Setiling Tahun 2019

\begin{tabular}{llrr}
\hline \multirow{2}{*}{ Wadah Kerjasama } & \multirow{2}{*}{ Interval } & Jumlah Responden & $\%$ \\
\cline { 3 - 4 } & & Orang & 26,7 \\
Berperan & $14-18$ & 8 & 73,3 \\
Kurang Berperan & $10-13$ & 22 & 0 \\
Tidak Berperan & $5-9$ & 0 & 100,0 \\
\hline Jumlah & & 30 & 0 \\
\hline
\end{tabular}

Sumber: Data primer diolah Tahun 2019

Berdasarkan hasil peran kelompok tani sebagai wadah kerjasama di Desa Setiling termasuk dalam kategori "Kurang Berperan", dimana dari seluruh responden yang terdiri dari 30 responden hanya 8 orang $(26,7 \%)$ yang berperan dalam kegiatan tersebut, hal ini menggambarkan bahwa peran kelompok tani sebagai wadah kerjasama masih kurang dalam kegiatan - kegiatan yang termasuk di dalam wadah kerjasama. Adapun indikator dalam peran kelompok sebagai wadah kerjasama antara lain:

\section{Kerjasama Antar Anggota Kelompok dan Kelompok Lain}

Kerjasama dapat menambah produktivitas dan meningkatkan moral pengurus. Kerjasama antar anggota kelompok maupun kelompok lain akan membuahkan hasil yang baik. Kerjasama akan dapat menambah tanggung jawab pengurus dalam melakukan tugas dengan baik, dan menambah kepuasan jika berhasil menyelesaikan tugas masing-masing. Kerjasama antar anggota kelompok dan kelompok lain memiliki kegiatan seperti:

Aturan kelompok

Aturan kelompok yang terbentuk melalui suatu proses interaksi diantara anggota yang kemudian akan disepakati secara bersama. Hasil penelitian menunjukkan bahwa semua responden yang terdiri dari 30 orang tahu adanya dan menyepakati adanya aturan kelompok. Aturan kelompok yang disepakati yaitu setiap anggota baru atau ingin menjadi anggota kelompok diharuskan membayar iuran wajib sebesar RP. 50.000. Iuran wajib tersebut digunakan untuk pengadaan kebutuhan kelompok berupa buku-buku administrasi kelompok, seperti buku tamu, buku keanggotaan, buku kas, proposal kegiatan dan sebagainya.

\section{Menyusun RDKK}

Rencana Definitif Kebutuhan Kelompok (RDKK) merupakan rencana kegiatan tani untuk satu tahun yang disusun berdasarkan kesepakatan. Hasil penelitian menunjukkan bahwa 15 orang (50\%) yang mengikuti atau mengetahui tentang penyusunan RDKK, 10 orang $(33,3 \%)$ yang mengetahui adanya penyusunan RDKK tetapi tidak mengikuti pertemuan tersebut, dan ada 5 orang $(16,7 \%)$ yang belum memiliki RDKK. Lima orang ini berasal dari kelompok tani Beriuk Demen yang memang belum menyusun RDKK, dikarenakan menurut anggota kelompok belum tau apa rencana definitif kebutuhan kelompok karena belum ada PPL yang turun untuk membantu menyusun RDKK kelompok.

\section{Menjual Hasil Secara Bersama}

Hasil penelitian menunjukkan bahwa 30 responden (100\%) sepakat untuk menjual hasil secara bersama. Anggota kelompok mengumpulkan hasil produksinya ke ketua kelompok untuk dijual secara bersama, yang menjadi alasan anggota untuk menjual hasil secara bersama adalah untuk mengurangi resiko dan menghemat biaya promosi, karena sebagian besar anggota kurang tau kemana akan memasarkan hasil produksinya selain pada pasar tradisional, maka dari itu anggota lebih memilih untuk menjual hasil secara bersama dibandingkan dengan menjual hasil secara pribadi.

\section{Bermita dengan Pihak Luar}

Bermitra dengan pihak luar adalah salah satu bentuk kerjasama yang harus di penuhi oleh kelompok tani, kerjasama tersebut dalam bentuk kemitraan yang saling menguntungkan. Kemitraan kelompok bisa dilakukan dengan pihak Desa, perusahaan swasta dan lembaga keuangan. Hasil penelitian menunjukkan bahwa kerjasama kelompok dengan pihak luar dalam bentuk mitra sudah dilakukan dengan pihak perusahaan swasta dan dari 30 responden hanya 15 responden (50\%) yang melakukan mitra dengan pihak luar. Sesuai dengan Kementrian Pertanian Republik Indonesia (2013) yang mengatakan kelompok tani diarahkan mampu menjalin kerjasama dan kemitraan usaha dengan pihak penyedia sarana produksi, pengolahan, pemasaran hasil/permodalan.

\section{Bermitra dengan Pihak BUMN/Desa}

Bermitra dengan pihak BUMN/Desa merupakan salah satu yang dapat menunjang kelompok khususnya anggota dalam meningkatkan produktivitas usahataninya dan meningkatkan pendapatan, namun 
kelompok tani di Desa Setiling belum ada yang melakukan hal tersebut, karena sosialisasi dan informasi yang kurang serta tidak adanya tawaran yang menjadikan kelompok tani tidak pernah bermitra dengan pihak Bumn/desa.

\section{Berimtra dengan Perusahaan}

Hasil penelitian menunjukkan bahwa kerjasama kelompok dengan pihak luar sudah dilakukan dengan pihak perusahaan swasta, di dalam kerjasama ini kedua belah pihak memiliki kesepakatan bersama dari segi kualitas produksi, pihak perusahaan memberikan kepercayaan kepada kelompok tani untuk menghasilkan produksi dengan kualitas yang terjamin, dan ini menjadi sebuah tantangan bagi kelompok tani untuk bisa mempertahankan kejaminan kualitas produksinya dengan mempelajari bagaimana teknik memetik yang baik, teliti pada saat pemanenan karena yang harus dipetik adalah biji kopi yang sudah berwarna merah, teknik pengolahan yang baik dan benar.

Dari hasil kerjasama dengan perusahaan tersebut responden mengaku mendapat keuntungan lebih banyak dibandingkan menjual hasil di pasaran, seperti yang diungkapkan oleh ketua kelompok Suka Maju, jika dipasaran harga kopi per kg seharga 30.000 sedangkan pada perusahaan ditawar dengan seharga 90.000/kg yang sudah menjadi bubuk kopi. Sesuai dengan Peraturan menteri pertanian nomor 83 tahun 2013 yang menyatakan kelompok tani harus mampu memperkuat kerjasama baik diantara sesama petani dalam poktan maupun dengan pihak luar. Melalui kerjasama ini diharapkan usahatani lebih efisien dan lebih mampu menghadapi ancaman, tantangan, hambatan, gangguan serta lebih menguntungkan.

\section{Bermitra dengan Lembaga Keuangan}

Lembaga keuangan atau koperasi mempunyai peran penting dalam menunjang keberhasilan dan pengembangan dalam berusahatani. Koperasi bisa menyediakan jasa peminjaman modal yang digunakan untuk membiayai proses usahatani. Namun karena koperasi belum ada di Desa Setiling sehingga belum ada responden anggota kelompok tani yang pernah bermitra dengan koperasi.

\section{Peran Kelompok Sebagai Unit Produksi}

Peran kelompok tani sebagai penyedia unit produksi adalah kemampuan kelompok dalam menyediakan sarana dan prasarana dalam menunjang kegiatan anggotanya, sehingga mampu meningkatkan skala ekonomis usaha yang dijalankan oleh kelompok maupun anggota kelompok dengan menjaga kuantitas maupun kontinuitas. Pada tabel 4.9 menunjukkan bahwa variabel peran kelompok sebagai unit produksi termasuk ke dalam kategori "Berperan" dengan jumlah responden sebanyak 15 orang (50\%). Peran kelompok tani sebagai unit produksi dilihat dari indikator sarana produksi dan hasil produksi. Peran kelompok sebagai unit produksi dapat dilihat dalam Tabel 4.5

Tabel 4. Jumlah Responden yang Berperan dalam Unit Produksi di Desa Setiling Tahun 2019

\begin{tabular}{llcc}
\hline \multirow{2}{*}{ Unit Produksi } & \multicolumn{3}{c}{ Jumlah Responden } \\
\cline { 2 - 4 } & Interval & Orang & $\%$ \\
\hline Berperan & $10-12$ & 15 & 50 \\
Kurang Berperan & $7-9$ & 15 & 50 \\
Tidak Berperan & $4-6$ & 0 & 0 \\
\hline Jumlah & & 30 & 100 \\
\hline
\end{tabular}

Sumber: Data primer diolah Tahun 2019

\section{Sarana Produksi}

Peran kelompok sebagai unit produksi digambarkan oleh adanya sarana produksi. Kelompok tani kopi di Desa Setiling mampu menjalankan perannya dan mampu meningkatkan keterampilan anggotanya melalui cara pemakaian mesin atau fasilitas bantuan dari Dinas. Kelompok mampu membantu kelancaran produksi usahatani kopi yang sedang dijalaninya dan mampu memberikan informasi dalam memanfaatkan peluang dan kesempatan berusaha. Akan tetapi untuk pengadaan mesin atas inisiatif dari kelompok belum bisa terpenuhi dikarenakan masalah modal, kelompok belum mampu membeli mesin sendiri dari uang kas yang ada, oleh karena itu kelompok berinisiatif membuat proposal usaha untuk bisa mendapatkan fasilitas dari pemerintah.

\section{Hasil Produksi}

Kelompok dapat menghubungkan anggotanya untuk memasarkan hasil produksinya di pameran pertanian yang diadakan oleh pemerintah, sehingga kelompok mendapatkan harga yang lebih tinggi. Dari 3 kelompok tani kopi yang terdapat di Desa Setiling hanya kelompok tani Suka Maju yang mampu mengembangkan produksi kopi nya menjadi produk yang berbeda di antara yang lain, seperti memproduksi kopi dengan 3 varian rasa diantaranya kopi dengan rasa coklat, rasa jahe dan rasa original. Hal ini menunjukkan 
bahwa hanya kelompok tani Suka Maju yang bisa menjalankan peran kelompok sebagai unit produksi secara optimal. Selain dalam pengembangan produk kelompok tani juga harus mampu mengidentifikasi kebutuhan pasar. Kelompok tani melalui seksi pemasaran telah membantu anggota dalam menjual hasil produksi dengan tingkat harga yang memuaskan.

\section{Kendala Anggota Kelompok dalam Pengembangan Usaha Kopi}

Kendala adalah suatu halangan yang bisa membuat anggota kelompok tidak bisa mengikuti kegiatan. Pelaksanaan kegiatan kelompok sebagai wadah belajar, wadah kerjasama dan unit produksi tidak lepas dari berbagai kendala dan hambatan anggota lain dari masing-masing anggota dan jadwal yang belum ditetapkan.

Berdasarkan hasil penelitian menunjukkan bahwa kendala anggota kelompok secara umum dalam mengikuti kegiatan sebagian besar adalah anggota kelompok memiliki kesibukan lain. Untuk lebih jelasnya dapat dilihat dalam Tabel 5 .

Tabel 5. Kendala Anggota dalam Pelaksanaan Peran Kelompok Tani di Desa Setiling Kecamatan Batukliang Utara Tahun 2019

\begin{tabular}{llllll}
\hline \multirow{2}{*}{ No } & Kendala yang dihadapi Anggota & \multicolumn{2}{c}{ Terkendala } & \multicolumn{2}{c}{ Tidak Terkendala } \\
\cline { 3 - 6 } & Orang & $\%$ & Orang & $\%$ \\
\hline 1. & $\begin{array}{l}\text { kurangnya sumber belajar } \\
\text { dari luar kelompok }\end{array}$ & 15 & 50 & 15 & 50 \\
2. & $\begin{array}{l}\text { Belum adanya kerjasama } \\
\text { dengan pihak luar }\end{array}$ & 15 & 50 & 15 & 50 \\
3. & Jadwal Pertemuan & 3 & 10 & 27 & 90 \\
4. & Pemasaran Produk & 15 & 50 & 15 & 50 \\
\hline
\end{tabular}

Sumber : Data primer diolah Pada Tahun 2019

Tabel 5 menunjukkan bahwa anggota kelompok tani memiliki kendala dalam pengembangan kelompok tani yang diantaranya :

\section{Kurangnya Sumber Belajar dari Luar Kelompok}

Sumber belajar merupakan suatu unsur yang memiliki peranan penting dalam menentukan proses belajar agar pembelajaran menjadi efektif dan efisien dalam pencapaian tujuan. Seperti diketahui bahwa kelompok sangat efektif sebagai wadah maupun sebagai pendekatan pembelajaran, di dalam proses belajar perlu adanya tutor atau narasumber dari pihak luar, akan tetapi dari hasil penelitian yang telah dilakukan didapatkan responden sebanyak 15 orang (50\%) terkendala dengan kurangnya sumber belajar dari luar kelompok, 15 responden ini berasal dari kelompok tani Beriuk Demen dan Mekar Baru dan hal ini yang menyebabkan kelompok kurang mampu untuk mengembangkan usahataninya. Dapat kita ketahui bahwa tutor mampu menjadi motivator, inspirator dengan baik bagi anggota kelompok, dimana tutor mampu mendorong anggota kelompok berpikir. Tutor mampu menciptakan situasi dimana anggota kelompok dihadapkan pada masalah, sehingga masalah tersebut mampu dipecahkan oleh kelompok itu sendiri.

\section{Belum Adanya Kerjasama dengan Pihak Luar}

Kerjasama kelompok tani adalah kerjasama antara anggota dengan pihak luar, baik dengan kelompok yang lain maupun pihak-pihak lain seperti: lembaga pemerintah, perusahaan, LSM dan lain sebagainya. Dari hasil penelitian yang telah dilakukan di dapatkan 15 responden $(50 \%)$ yang belum bekerjasama dengan pihak luar hal ini dikarenakan bahwa anggota kelompok tersebut kekurangan informasi dan kurangnya interaksi dengan kelompok lain maupun pihak luar dari anggota.

\section{Jadwal Pertemuan yang Tidak Terjadwal}

Kendala yang lainnya dihadapi anggota adalah kendala jadwal pertemuan, kendala pertemuan yang dihadapi oleh responden yaitu hanya 3 orang anggota (10\%). Kendala jadwal yang dirasakan oleh anggota adalah terkadang waktu kegiatan yang tidak terjadwal dan secara tiba-tiba sehingga anggota merasa sulit untuk menyesuaikan waktu yang mendadak. Seperti salah satunya mengikuti kegiatan pertemuan rutin yang waktunya terkadang tidak sesuai dengan jadwal yang sudah ditetapkan, anggota tidak bisa mengikuti kegiatan tersebut, karena anggota yang terkendala memiliki pekerjaan pokok sebagai Kades, Sekdes dan Guru dan inilah menjadi permasalahan mengapa jadwal harus ditentukan sehingga ketika mendadak mendapatkan informasinya, tidak merasa berat untuk mengikuti kegiatan, namun dari keseluruhan anggota hanya sebagian kecil yang menganggap jadwal sebagai kendala, hal tersebut secara umum dalam kelompok tidak menjadi kendala besar untuk dibatalkannya kegiatan, kegiatan tetap dilakukan dengan tanpa anggota yang mengalami kendala tersebut. 


\section{Pemasaran Produk}

Pemasaran produk adalah suatu kegiatan yang harus dilakukan untuk memperkenalkan produk secara lebih luas ke masyarakat. Dari hasil penelitian yang telah dilakukan didapatkan 15 responden (50\%) yang belum bisa memasarkan produknya secara meluas, 15 responden ini termasuk kelompok tani Beriuk Demen dan Mekar Baru, sedangkan kelompok tani Suka Maju sudah bisa memasarkan hasil produksinya dan sudah memiliki brand sendiri, akan tetapi belum secara maksimal dalam pemasarannya. Strategi pemasaran bisa dilakukan melalui media sosial yang merupakan alat pemasaran yang paling ampuh, sehingga produk yang ditawarkan memiliki peluang besar untuk terjual. Kemudian untuk memasarkan produk juga bisa dengan memilih tempat yang strategis, karena dengan tempat penjualan yang strategis memiliki kemungkinan memicu penjualan yang tinggi, seperti di pusat oleh-oleh dan lain sebagainya.

\section{KESIMPULAN DAN SARAN}

\section{Kesimpulan}

Berdasarkan hasil penelitian, maka kesimpulan yang dapat ditarik dari penelitian ini adalah Peran kelompok tani di Desa Setiling termasuk kedalam kategori "Berperan". Adapun peran kelompok tani dapat dibedakan menjadi beberapa variabel yaitu wadah belajar, wadah kerjasama dan unit produksi. Dari penelitian yang sudah dijalankan didapatkan hasil peran kelompok tani sebagai wadah belajar sebesar 56,7\%, wadah kerjasama 26,7\% dan unit produksi sebesar 50\%. Dapat dilihat bahwa peran kelompok dalam pengembangan kelompok tani kopi yang berjalan optimal adalah wadah belajar dan unit produksi. Kendala anggota dalam pelaksanaan kegiatan kelompok tani yang merupakan wujud dari peran kelompok tani dalam pengembangan usaha tani kopi sebagai wadah belajar, wadah kerjasama dan unit produksi adalah sebagian besar anggota kelompok mengatakan kurangnya sumber belajar dari luar, kurangya kerjasama dengan pihak luar, jadwal pertemuan yang tidak terjadwal, dan masih minimnya pemasaran produksi.

Saran

Berdasarkan hasil penelitian, pembahasan dan kesimpulan, peneliti menunjukkan beberapa saran yaitu Untuk kelompok tani, seharusnya memiliki inisiatif untuk mencari narasumber untuk meningkatkan motivasi anggota kelompok dan lebih meningkatkan pengetahuan anggota kelompok, menetapkan jadwal untuk kegiatankegiatan mendasar seperti pertemuan rutin supaya kegiatan tersebut bisa diikuti anggota secara maksimal, mencari informasi untuk bekerjasama dengan pihak luar agar kelompok tani bisa meningkatkan interaksi yang bertujuan untuk lebih mengembangkan usaha dalam kelompok dan memanfaatkan sosial media atau tempattempat strategis lainnya seperti pusat oleh-oleh, toko- toko terkenal dan lain sebagainya untuk memasarkan produk.

\section{DAFTAR PUSTAKA}

Badan Penyuluhan dan Pengembangan SDM Pertanian. 2013. Peraturan Kepala Badan Penyuluhan dan Pengembangan Sumberdaya Manusia Pertanian No.168/Per/SM.170/J/11/11 tentang Petunjuk Pelaksanaan Penilaian Kemampuan Kelompok Tani. Jakarta: Badan Penyuluhan dan Pengembangan SDM Pertanian.

Dinas Pertanian Lombok Tengah. 2017. Kabupaten Lombok Tengah Dalam Angka Tahun 2017. Dinas Pertanian. Lombok Tengah.

Kementrian Pertanian Republik Indonesia. 2013. Pembangunan Pertanian Untuk Mengangkat Kesejahteraan Petani. Jakarta 12550. Indonesia.

Mailina, H. 2018. Peran Penyuluh Pertanian Dalam Pengembangan Kelompok Tani Tanaman Kopi (coffe) (studi kasus : di Desa Jongkok Raya Kec. Bandar Kab. Bener Meriah). JASC. Volume 01 No 02. April 2018. 128-134

Peraturan Menteri Pertanian Nomor 83. 2013. Pedoman Pembinaan Kelompok Tani dan Gabungan Kelompok Tani. Kementan. Diakses, 16 Januari 2019. 